\title{
Enhanced photochemical oxidation ability of carbon nitride by $\pi-\pi$ stacking interactions with graphene
}

\author{
Qiang Hao, Simeng Hao, Xiuxiu Niu, Xun Li, Daimei Chen*, Hao Ding \# \\ Beijing Key Laboratory of Materials Utilization of Nonmetallic Minerals and Solid Wastes, National Laboratory of Mineral Materials, School of Materials \\ Science and Technology, China University of Geosciences, Beijing 100083, China
}

\section{A R T I C L E I N F O}

Article history:

Received 20 August 2016

Accepted 26 September 2016

Published 5 February 2017

\section{Keywords:}

Graphitic carbon nitride

Graphene oxide

$\pi-\pi$ stacking

Photocatalyst

Interaction

\begin{abstract}
A B S T R A C T
A one-pot method for the preparation of g- $\mathrm{C}_{3} \mathrm{~N}_{4} /$ reduced graphene oxide ( $\mathrm{rGO}$ ) composite photocatalysts with controllable band structures is presented. The photocatalysts are characterized by Fouirer transform infrared spectroscopy, X-ray diffraction, scanning electron microscope, transmission electron microscope, and Mott-Schottky analysis. The valance band (VB) of g- $\mathrm{C}_{3} \mathrm{~N}_{4}$ exhibits a noticeable positive shift upon hybridizing with $\mathrm{rGO}$, and thus results in a strong photo-oxidation ability. The g- $\mathrm{C}_{3} \mathrm{~N}_{4} / \mathrm{rGO}$ composites show a higher photodegradation activity for 2,4-dichlorophenol (2,4-DCP) and rhodamine B (RhB) under visible light irradiation $(\lambda \geq 420 \mathrm{~nm})$. The g- $\mathrm{C}_{3} \mathrm{~N}_{4} / \mathrm{rGO}-1$ sample exhibits the highest photocatalytic activity, which is 1.49 and 1.52 times higher than that of bulk g- $\mathrm{C}_{3} \mathrm{~N}_{4}$ for 2,4-DCP and 1.52 times degradation, respectively. The enhanced photocatalytic activity for $\mathrm{g}-\mathrm{C}_{3} \mathrm{~N}_{4}$ originates from the improved visible light usage, enhanced electronic conductivity and photo-oxidation ability by the formed strong $\pi-\pi$ stacking interactions with rGO.
\end{abstract}

(C) 2016, Dalian Institute of Chemical Physics, Chinese Academy of Sciences. Published by Elsevier B.V. All rights reserved.

\section{Introduction}

The synthesis of advanced photocatalysts has attracted much attention since their potential applications in environmental purification and hydrogen production $[1,2]$. Among the semiconductors, $\mathrm{TiO}_{2}$ has been studied the most widely owing to its excellent photocatalytic activity, good stability and non-toxicity [3-5]. However, owing to the limitation of the wide band gap $(3.2 \mathrm{eV}), \mathrm{TiO}_{2}$ cannot use visible light. To effectively use solar energy, investigations of visible-light photocatalysts have attracted a great deal of attention. A large number of photocatalysts with a high efficiency under the irradiation of visible light, such as modified $\mathrm{TiO}_{2}$ [6,7], sulfides [8,9], oxynitrides $[10,11]$ and Bi-based composite oxides [12-14], have successfully been designed and exploited.

As a metal-free polymeric photocatalyst, graphitic carbon nitride $\left(\mathrm{g}-\mathrm{C}_{3} \mathrm{~N}_{4}\right)$ has recently been intensively investigated for its potential practical applications, considering its high stability, good biocompatibility, nontoxicity and controllable band structures [15]. This material can be applied for the conversion of solar energy into electrical energy or chemical energy. Compared with the traditional inorganic photocatalytic materials, such as $\mathrm{TiO}_{2}$ [16-18] and $\mathrm{ZnO}$ [19-21], g- $\mathrm{C}_{3} \mathrm{~N}_{4}$ has a narrower band gap (2.7 eV). This is a key property for its ability to absorb

\footnotetext{
* Corresponding author. Tel: +86-15801558907; Fax: +86-10 82322974; E-mail: chendaimei@cugb.edu.cn

\# Corresponding author. E-mail: dinghao@cugb.edu.cn

This work was supported by the National Natural Science Foundation of China (21577132), the Fundamental Research Funds for the Central Universities (2652015225), National High Technology Research and Development Program of China (2012AA062701), Students Innovation and Entrepreneurship Training Program 2015 of China University of Geosciences (201511415069), Beijing Key Laboratory of Materials Utilization of Nonmetallic Minerals and Solid Wastes DOI: 10.1016/S1872-2067(16)62561-5 | http://www.sciencedirect.com/science/journal/18722067 | Chin. J. Catal., Vol. 38, No. 2, February 2017
} 
visible light to realize a visible light response range of the photocatalyst. Nevertheless, $\mathrm{g}-\mathrm{C}_{3} \mathrm{~N}_{4}$ still has some shortcomings, for instance, its redox ability is weak, its spectral response range is not sufficiently wide and the transport efficiency of its photogenerated charge carriers is low $[12,20]$. Therefore, it is difficult for $\mathrm{g}-\mathrm{C}_{3} \mathrm{~N}_{4}$ to be used for practical application. To address these problems, a number of methods have been determined for the modification of pure $\mathrm{g}-\mathrm{C}_{3} \mathrm{~N}_{4}$, such as post-functionalization, semiconductor coupling, texture tuning by templates and band gap modification by heteroatom doping [22-25].

Graphene has a perfect two-dimensional (2D) crystal structure. It is composed of hexagonal carbon rings in a single atomic layer [26]. Graphene exhibits many interesting electronic and optoelectronic properties, which have recently attracted much interest in a wide range of fields. Particularly, it can be used as an electron mediator for shuttling electrons, leading to the effective separation of photogenerated charge carriers at the junction interface. Owing to its outstanding performance, graphene has already been used in combination with semiconductors for an enhancement of the photocatalytic performance $[27,28]$. Coupling graphene with $\mathrm{g}-\mathrm{C}_{3} \mathrm{~N}_{4}$ is regarded as an effective method for improving the conductivity and electrocatalytic performance of g- $\mathrm{C}_{3} \mathrm{~N}_{4}[29,30]$. Especially, both graphene and g- $\mathrm{C}_{3} \mathrm{~N}_{4}$ have the 2D nanosheet structure, which can be constructed into a layered junction, consequently increasing the contact area for efficient charge transfer at the interface. However, the bottom of the conduction band (CB) of $\mathrm{g}-\mathrm{C}_{3} \mathrm{~N}_{4}$ is located at approximately $-1.3 \mathrm{~V}$, normal hydrogen electrode (NHE) ( $\mathrm{pH}=7$ ), which is sufficient for hydrogen photogeneration. Therefore, graphene in the $\mathrm{g}-\mathrm{C}_{3} \mathrm{~N}_{4}$ /reduced graphene oxide (rGO) junction has generally been used as an electron mediator for increasing the reactivity of g- $\mathrm{C}_{3} \mathrm{~N}_{4}$. The valance band (VB) of g- $\mathrm{C}_{3} \mathrm{~N}_{4}$ is located at approximately $1.4 \mathrm{~V}$, hence, its efficiency for the oxidation and mineralization of organic pollutants is not high. An urgent requirement is to improve the photo-oxidation ability of g- $\mathrm{C}_{3} \mathrm{~N}_{4}$ for environmental application. More importantly, both g- $\mathrm{C}_{3} \mathrm{~N}_{4}$ and graphene have a natural $\pi-\pi$ conjugated structure $[31,32]$ and can easily be hybridized owing to the strong $\pi-\pi$ stacking interactions. Thus, the introduction of graphene could obviously shift the highest occupied molecular orbital (HOMO) of g- $\mathrm{C}_{3} \mathrm{~N}_{4}$ to lower energies through $\pi-\pi$ or charge-transfer interactions [25], resulting in the enhancement of the photo-oxidation ability. Therefore, it is expected that the introduction of graphene can not only improve the electron transfer efficiency, but also lower the VB location of g- $\mathrm{C}_{3} \mathrm{~N}_{4}$. However, in most reports, graphene has generally been used to improve the electron transfer of the catalysts. The modification of the band gap of the semiconductor through $\pi-\pi$ stacking interactions has seldom been studied.

Herein, we report a one-pot synthesis of g- $\mathrm{C}_{3} \mathrm{~N}_{4} / \mathrm{rGO}$ composites using melamine and GO as the precursors. rGO can readily hybridize with $\mathrm{g}-\mathrm{C}_{3} \mathrm{~N}_{4}$ through strong $\pi-\pi$ stacking interactions. The introduction of rGO is obviously able to shift the HOMO of $\mathrm{g}-\mathrm{C}_{3} \mathrm{~N}_{4}$ to lower energies through $\pi-\pi$ interactions, resulting in the enhancement of the photo-oxidation ability of g- $\mathrm{C}_{3} \mathrm{~N}_{4}$. The photocatalytic activities of g- $\mathrm{C}_{3} \mathrm{~N}_{4} / \mathrm{rGO}$ composites were evaluated by the degradation of aqueous 2,4-DCP and RhB solutions under visible light irradiation.

\section{Experimental}

\subsection{Synthesis of $g-C_{3} N_{4} / r G O$ samples}

All chemicals used were reagent grade and used without further purification. The graphene oxide (GO) was prepared by Hummers' method [33]. The typical g- $\mathrm{C}_{3} \mathrm{~N}_{4} / \mathrm{rGO}$ composite was prepared as follows. Suspensions of GO $(0.01 \mathrm{~g} / \mathrm{mL})$ were made by dispersing $2.5 \mathrm{~g}$ of GO in $250 \mathrm{~mL}$ of ultra-pure water. A certain amount of GO suspension was mixed with $10 \mathrm{~mL}$ of melamine aqueous suspension $(0.2 \mathrm{~g} / \mathrm{mL})$ under ultrasonication for $2 \mathrm{~h}$. The resultant suspension was dried at $90^{\circ} \mathrm{C}$ for $12 \mathrm{~h}$. Finally, the obtained powder was heated to $540{ }^{\circ} \mathrm{C}$ within 135 min and kept at this temperature for $4 \mathrm{~h}$ under air. The mass ratios of GO to melamine were controlled at $0.5 \%, 1.0 \%, 3.0 \%$ and $5.0 \%$, and the resulting samples were referred to as g- $\mathrm{C}_{3} \mathrm{~N}_{4} / \mathrm{rGO}-0.5, \quad$ g- $\mathrm{C}_{3} \mathrm{~N}_{4} / \mathrm{rGO}-1, \quad$ g- $\mathrm{C}_{3} \mathrm{~N}_{4} / \mathrm{rGO}-3 \quad$ and g- $\mathrm{C}_{3} \mathrm{~N}_{4} / \mathrm{rGO}-5$, respectively.

\subsection{Characterization}

The crystallinity of the g- $\mathrm{C}_{3} \mathrm{~N}_{4} / \mathrm{rGO}$ samples was tested by X-ray diffraction (XRD) on a Bruker D8 Advance X-ray diffractometer at $25{ }^{\circ} \mathrm{C}$. Morphologies and structures of the prepared samples were examined with a Hitachi HT770 transmission electron microscope (TEM) operated at an accelerating voltage of $100 \mathrm{kV}$ and a Hitachi SU-8010 field emission scanning electron microscope (SEM) at $10 \mathrm{kV}$ and $5 \mu \mathrm{A}$. $\mathrm{BaSO}_{4}$ was used as the reference to test the ultraviolet-visible (UV-vis) diffuse reflectance spectra (DRS) of the samples on a Hitachi U-3010 UV-vis spectrophotometer. A Bruker spectrometer was used to obtain the Fourier transform infrared (FTIR) spectra in the wavenumber range of 4000-600 $\mathrm{cm}^{-1}$ with a resolution of 1 $\mathrm{cm}^{-1}$. The $\mathrm{N}_{2}$ adsorption-desorption analysis was performed on a Micromeritics ASAP2010 V5.02H automatic physical and chemical adsorption instrument. Electrochemical and photoelectrochemical measurements were performed in three-electrode quartz cells with a $\mathrm{Na}_{2} \mathrm{SO}_{4}$ electrolyte solution $(0.1 \mathrm{~mol} / \mathrm{L})$. Saturated calomel electrodes (SCE) were used as the reference electrodes, and platinum wire was used as the counter electrode. The as-prepared photocatalyst film electrodes on ITO served as the working electrode. The photocurrents were measured on an electrochemical system (CHI-660B, China). Photoluminescence (PL) spectra of the prepared samples in aqueous suspensions were obtained at $25^{\circ} \mathrm{C}$ under excitation by incident light of $375 \mathrm{~nm}$ using a Hitachi F-4600 fluorescence spectrometer. X-ray photoelectron spectroscopy (XPS) of the as-prepared samples was obtained after vacuum deoxidation from a PHI Quantera XPS microprobe. Raman spectroscopy was obtained from a Horiba HR 800 laser confocal micro Raman spectrometer using a laser at $514 \mathrm{~nm}$. The suspensions of the samples were prepared by dispersing $5 \mathrm{mg}$ of the as-prepared samples in $500 \mu \mathrm{L}$ of ultra-pure water under sonication for $1 \mathrm{~h}$. The electron paramagnetic resonance (ESR) 
spectra were recorded on a Bruker ESR 300E, using the radical scavenger dimethyl pyridine $\mathrm{N}$-oxide (DMPO).

\subsection{Photocatalytic activity}

The photocatalytic activities of the as-prepared samples were evaluated by the decomposition of 2,4-dichlorophenol and $\mathrm{RhB}$ under visible light irradiation. The visible light source was obtained by a 500-W Xe lamp with a cutoff filter (420 nm) and the average light intensity was $35 \mathrm{~mW} / \mathrm{cm}^{2}$.

$50 \mathrm{mg}$ of photocatalyst was well-dispersed in an aqueous solution of 2,4-dichlorophenol (50 mL, $5 \mathrm{ppm})$ or $\mathrm{RhB}(50 \mathrm{~mL}$, $5 \mathrm{ppm}$ ). Prior to light irradiation, the suspensions were first ultrasonically dispersed in the dark for $15 \mathrm{~min}$, then magnetically stirred for $120 \mathrm{~min}$ to reach adsorption-desorption equilibrium. Then, the Xe lamp was turned on, and $3.0 \mathrm{~mL}$ aliquots were sampled at given time intervals and filtered with a micropore membrane (diameter of $0.45 \mu \mathrm{m}$, Jin Teng company). High-performance liquid chromatography (HPLC) (Shimadzu LC-20AT) was adopted to detect 2,4-dichlorophenol concentration. The mobile phase was methanol and water (volume ratio: $75 / 25$ ), the elution time was $7 \mathrm{~min}$, the flow rate was 1 $\mathrm{mL} / \mathrm{min}$, detection wavelength was $270 \mathrm{~nm}$ and the chromatographic column was a Venusil XBP-C18 (3.9 × 200, Agela Technologies Inc.) column. The concentration of RhB was analyzed by recording the absorbance at the characteristic band of 553 nm using a UV-vis spectrophotometer (HITACHI U-3100). The degradation efficiency (\%) was calculated as follows:

Degradation $(\%)=\left(C_{0}-C\right) / C_{0} \times 100 \%$

where $C_{o}$ is the initial concentration of $\mathrm{RhB}$, and $C$ is the $\mathrm{RhB}$ concentration at time $t$.

\section{Results and discussion}

\subsection{Morphology and structure of $g-C_{3} N_{4} / r G O$ samples}

Fig. 1 shows the XRD patterns of as-prepared $g-\mathrm{C}_{3} \mathrm{~N}_{4} / \mathrm{rGO}$ samples. Two distinct diffraction peaks ascribed to $\mathrm{g}-\mathrm{C}_{3} \mathrm{~N}_{4}$ (JCPDS 87-1526) can be observed in all these samples. The stronger peak at $27.1^{\circ}$ can be attributed to the (002) crystal plane diffraction peak and represents interplanar graphitic

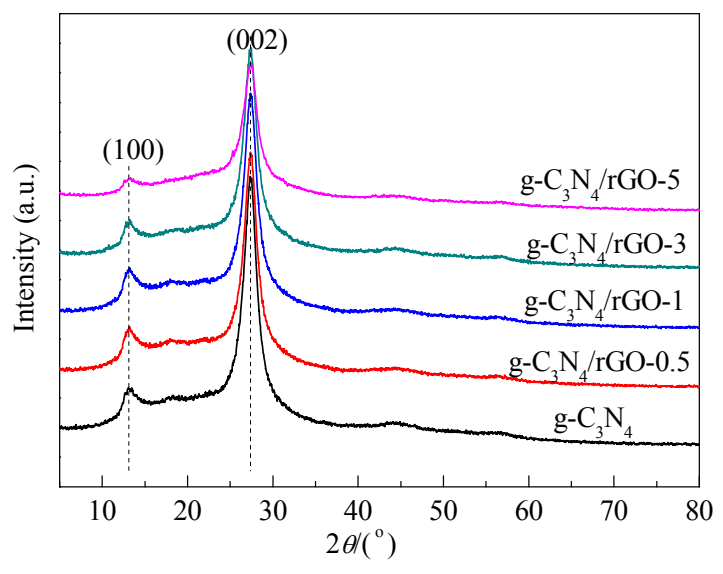

Fig. 1. XRD patterns of g- $\mathrm{C}_{3} \mathrm{~N}_{4}$ and g- $\mathrm{C}_{3} \mathrm{~N}_{4} / \mathrm{rGO}$ samples. stacking with an interlayer distance of $0.33 \mathrm{~nm}$. The small peak at approximately $13.1^{\circ}$ corresponds to the (100) diffraction peak and represents an interplanar separation of $0.68 \mathrm{~nm}$ $[34,35]$. This means that the rGO modification did not transform the structure of $\mathrm{g}-\mathrm{C}_{3} \mathrm{~N}_{4}$. However, with an increasing amount of rGO, the two peaks gradually became weaker, which means the introduction of $\mathrm{rGO}$ decreases the crystallinity of g- $\mathrm{C}_{3} \mathrm{~N}_{4}$. Furthermore, the peaks of rGO cannot be observed in the XRD patterns and the crystallization disappeared, suggesting that rGO might be uniformly combined with $\mathrm{g}-\mathrm{C}_{3} \mathrm{~N}_{4}$.

Fig. 2 shows the FT-IR spectra of $\mathrm{g}^{-} \mathrm{C}_{3} \mathrm{~N}_{4}, \mathrm{GO}$ and the g- $\mathrm{C}_{3} \mathrm{~N}_{4} / \mathrm{rGO}$ samples. For all the tested samples, the peak at $1629 \mathrm{~cm}^{-1}$ is attributed to the $\mathrm{C}=\mathrm{N}$ stretching vibration modes, while the peaks at 1228, 1318 and $1403 \mathrm{~cm}^{-1}$ are assigned to the aromatic C-N stretching [36-38]. The peak at $808 \mathrm{~cm}^{-1}$ is the typical bending vibration of s-triazine units [39]. The stretching mode of $-\mathrm{OH}$ and the physically adsorbed $\mathrm{H}_{2} \mathrm{O}$ cause a broad peak at $3000-3700 \mathrm{~cm}^{-1}$ in the spectra of GO. The C-O stretching mode of $\mathrm{COOH}$ groups and deformation vibration of intercalated water cause two peaks at 1732 and $1622 \mathrm{~cm}^{-1}$, respectively. For the $\mathrm{rGO} / \mathrm{g}-\mathrm{C}_{3} \mathrm{~N}_{4}$ composites, only the characteristic peaks of $\mathrm{CN}$ heterocycles in $\mathrm{g}-\mathrm{C}_{3} \mathrm{~N}_{4}$ appeared, while those of rGO were not observed, because of the low quantity of GO in the composites. After calcination, the characteristic functional groups of GO all disappeared, indicating that GO had been transformed to rGO.

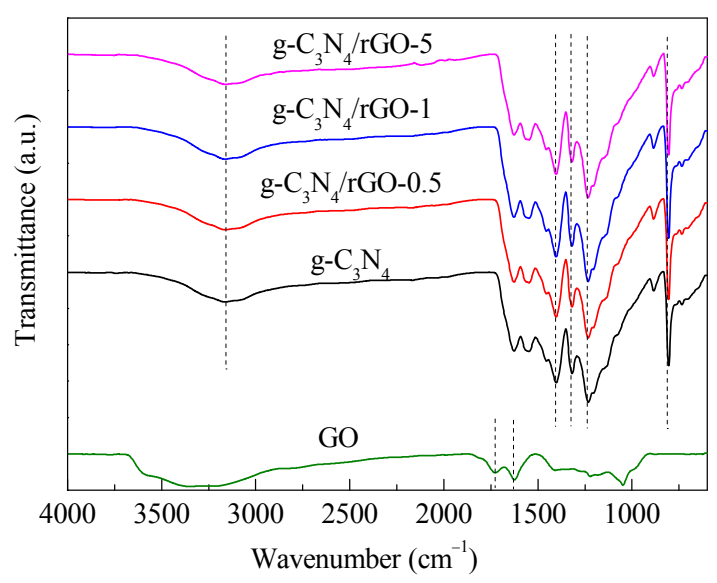

Fig. 2. FT-IR spectra of g- $\mathrm{C}_{3} \mathrm{~N}_{4}, \mathrm{GO}$ and g- $\mathrm{C}_{3} \mathrm{~N}_{4} / \mathrm{rGO}$ samples.

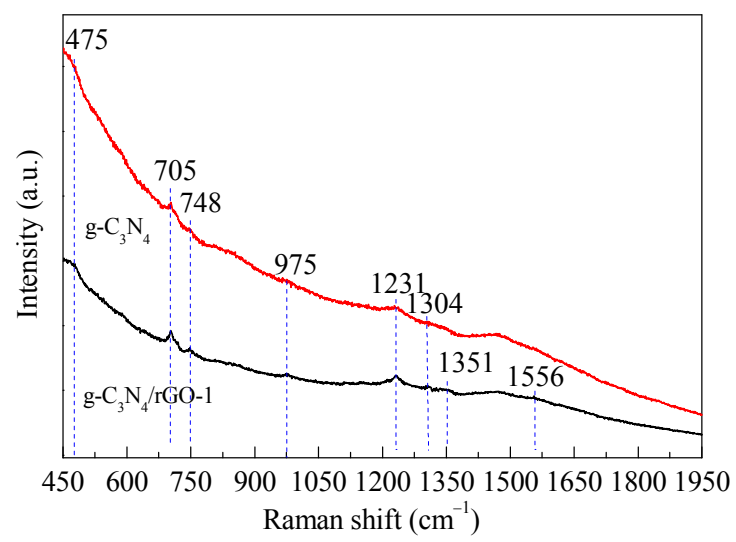

Fig. 3. Raman spectra of the $g-\mathrm{C}_{3} \mathrm{~N}_{4}$ and $g-\mathrm{C}_{3} \mathrm{~N}_{4} / \mathrm{rGO}-1$. 
The Raman spectra is used to further confirm the presence of graphene in $\mathrm{g}-\mathrm{C}_{3} \mathrm{~N}_{4} / \mathrm{rGO}$ composites. Fig. 3 shows the Raman spectra of $\mathrm{g}-\mathrm{C}_{3} \mathrm{~N}_{4}$ and $\mathrm{g}-\mathrm{C}_{3} \mathrm{~N}_{4} / \mathrm{rGO}-1$. Several characteristic peaks of $\mathrm{g}^{-} \mathrm{C}_{3} \mathrm{~N}_{4}$ at 475, 705, 748, 975, 1231 and $1301 \mathrm{~cm}^{-1}$ were observed. For g- $\mathrm{C}_{3} \mathrm{~N}_{4} / \mathrm{rGO}-1$, all the Raman bands for g- $\mathrm{C}_{3} \mathrm{~N}_{4}$ can be found, moreover, two new peaks at 1351 and $1556 \mathrm{~cm}^{-1}$ can be observed, which are ascribed to the presence of graphene [30].

Fig. 4 shows the survey data of the samples and the higher resolution spectra of the $\mathrm{C} 1 s, \mathrm{~N} 1 s$ and $01 s$ peaks. In Fig. 4(a), the XPS survey spectra of pure $\mathrm{g}-\mathrm{C}_{3} \mathrm{~N}_{4}$ shows only carbon and nitrogen elements. However, that of the g- $\mathrm{C}_{3} \mathrm{~N}_{4} / \mathrm{rGO}$ composite obviously shows the presence of $\mathrm{C}, \mathrm{N}$ and $\mathrm{O}$ elements, indicating the incorporation of elemental oxygen into the framework of the g- $\mathrm{C}_{3} \mathrm{~N}_{4} / \mathrm{rGO}$ composite [40,41]. Fig. 4(b) shows the high resolution C1s XPS spectra of pure g- $\mathrm{C}_{3} \mathrm{~N}_{4}$ and g- $\mathrm{C}_{3} \mathrm{~N}_{4} / \mathrm{rGO}$. Both samples exhibit three peaks at 288.8, 288.2 and $284.8 \mathrm{eV}$. The peaks at 288.8 and $288.2 \mathrm{eV}$ could be assigned to the $s p^{2} \mathrm{C}$ atoms bonded to $\mathrm{N}$ in the sample. The smaller peak at $284.8 \mathrm{eV}$ is related to the $\mathrm{C}-\mathrm{C}$ bonds of graphitic or adventitious carbons. Different from bulk $\mathrm{g}-\mathrm{C}_{3} \mathrm{~N}_{4}$, the $\mathrm{C} 1 s$ XPS spectrum of
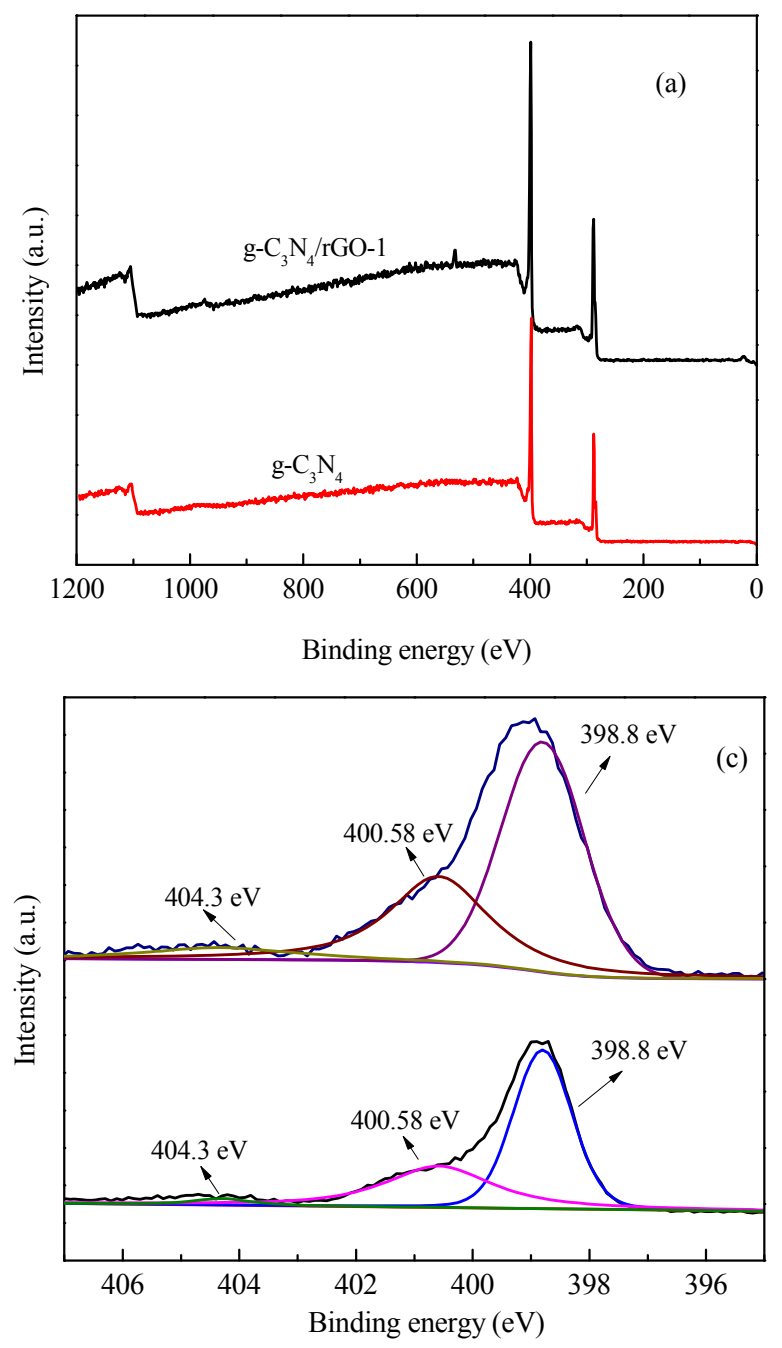

g- $\mathrm{C}_{3} \mathrm{~N}_{4} / \mathrm{rGO}-1$ shows a new peak at $287.8 \mathrm{eV}$, which is attributed to the formation of $\mathrm{C}-\mathrm{O}-\mathrm{C}$ bonding configurations during thermal treatment [42]. Three peaks were observed at 404.3, 400.58 and $398.8 \mathrm{eV}$ in the N1s XPS spectra of both $\mathrm{g}-\mathrm{C}_{3} \mathrm{~N}_{4}$ and g- $\mathrm{C}_{3} \mathrm{~N}_{4} / \mathrm{rGO}-1$ (Fig. 4(c)), implying the presence of three types of $\mathrm{N}$ bonding in the samples. The dominant $\mathrm{N} 1 s$ peak at 398.8 $\mathrm{eV}$ is associated with $s p^{2}$ hybridized nitrogen involved in triazine rings, while the peak at a binding energy of approximately $400.58 \mathrm{eV}$ is assigned to the bridging $\mathrm{N}$ atoms in $\mathrm{N}(\mathrm{C})_{3}$ or $\mathrm{N}$ bonded with $\mathrm{H}$ atoms. The weak peak located at $404.3 \mathrm{eV}$ can be attributed to the charging effects arising from the $\pi$-excitation [40]. More importantly, for $\mathrm{g}-\mathrm{C}_{3} \mathrm{~N}_{4} / \mathrm{rGO}-1$, the peak area at $404.3 \mathrm{eV}$ is larger than that of pure $\mathrm{g}-\mathrm{C}_{3} \mathrm{~N}_{4}$ indicating a stronger $\pi-\pi$ conjugate interaction. The above results show that most oxygen functional groups in GO can be removed after $540{ }^{\circ} \mathrm{C}$ thermal treatment, but the remaining $-\mathrm{OH}$ groups can act as the cross-linker for forming $\mathrm{C}-\mathrm{O}-\mathrm{C}$ bonds responsible for the narrowed bandgap of the composites.

The morphologies of the $\mathrm{g}-\mathrm{C}_{3} \mathrm{~N}_{4} / \mathrm{rGO}$ samples were examined by SEM and TEM. As can be seen in Fig. 5, rGO displays a two-dimensional structure crumpled into thin multilayer
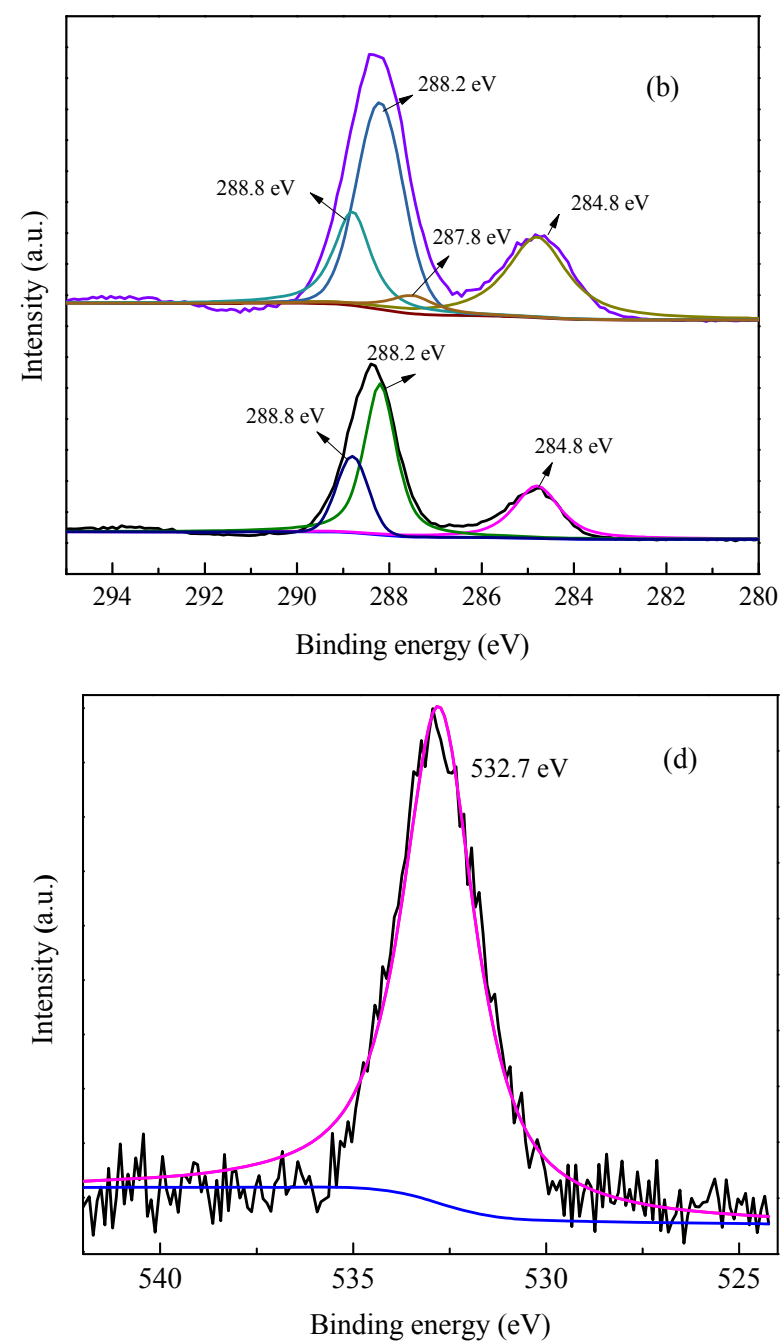

Fig. 4. (a) XPS survey spectra of the synthesized g- $\mathrm{C}_{3} \mathrm{~N}_{4}$ and g- $\mathrm{C}_{3} \mathrm{~N}_{4} / \mathrm{rGO}-1$ samples. High resolution C1s (b), $\mathrm{N} 1 s$ (c) and $01 s$ (d) spectra of pure g- $\mathrm{C}_{3} \mathrm{~N}_{4}$ and $\mathrm{g}-\mathrm{C}_{3} \mathrm{~N}_{4} / \mathrm{rGO}-1$ samples. 

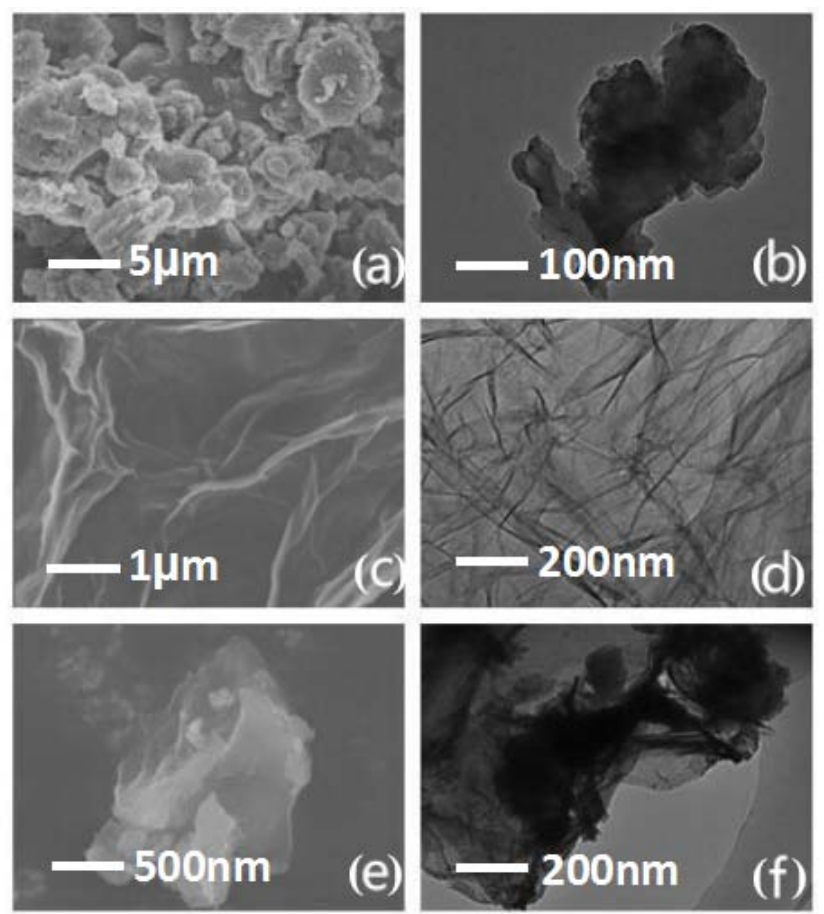

Fig. 5. SEM (a, c, e) and TEM (b, d, f) micrographs of $\mathrm{g}-\mathrm{C}_{3} \mathrm{~N}_{4} / \mathrm{rGO}$ samples. $(\mathrm{a}, \mathrm{b}) \mathrm{g}-\mathrm{C}_{3} \mathrm{~N}_{4}$; (c) graphene oxide, (d) reduced graphene oxide, (e, f) g- $\mathrm{C}_{3} \mathrm{~N}_{4} / \mathrm{rGO}-1$.

sheets, and pure g- $\mathrm{C}_{3} \mathrm{~N}_{4}$ shows the agglomeration of the lamellar structure. In comparison to $\mathrm{rGO}$, the $\mathrm{g}-\mathrm{C}_{3} \mathrm{~N}_{4} / \mathrm{rGO}$ sample exhibits a more compact structure because g- $\mathrm{C}_{3} \mathrm{~N}_{4}$ was sandwiched between $\mathrm{rGO}$ sheets through polymerization of melamine molecules preadsorbed on the GO sheets. This sandwiched structure can facilitate the formation of $\pi-\pi$ conjugated structure between $\mathrm{g}-\mathrm{C}_{3} \mathrm{~N}_{4}$ and $\mathrm{rGO}$.

Fig. 6 shows the UV-vis diffuse reflectance spectra of g- $\mathrm{C}_{3} \mathrm{~N}_{4}$ and g- $\mathrm{C}_{3} \mathrm{~N}_{4} / \mathrm{rGO}$ samples. Pure g- $\mathrm{C}_{3} \mathrm{~N}_{4}$ exhibited an absorption edge at $460 \mathrm{~nm}$, corresponding to an optical band gap of 2.70 $\mathrm{eV}$. With an increasing rGO content, the absorption edge of the g- $\mathrm{C}_{3} \mathrm{~N}_{4} / \mathrm{rGO}$ composites showed an obvious redshift, which was attributed to the $\pi-\pi$ stacking and the assembly of $g-C_{3} N_{4}$ and rGO. Furthermore, the g- $\mathrm{C}_{3} \mathrm{~N}_{4} / \mathrm{rGO}$ composites show a broad

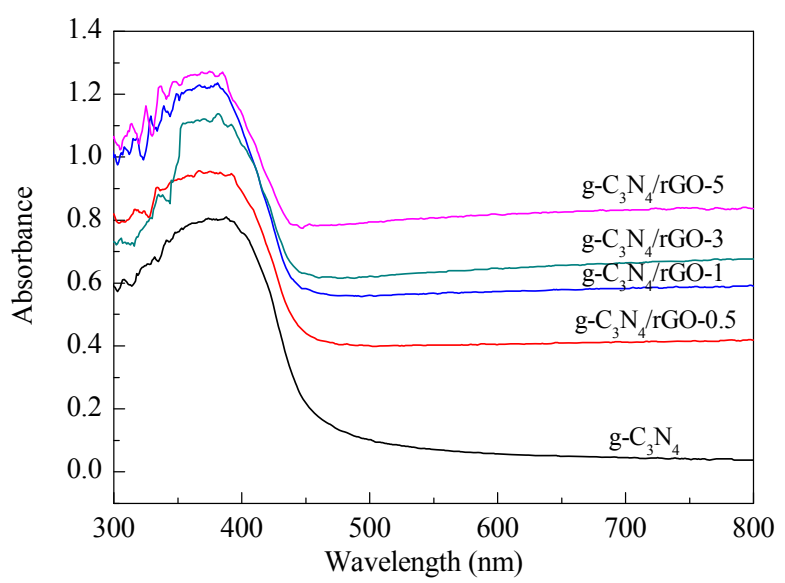

Fig. 6. UV-vis diffuse reflectance spectra of g- $\mathrm{C}_{3} \mathrm{~N}_{4}$ and $g-\mathrm{C}_{3} \mathrm{~N}_{4} / \mathrm{rGO}$ samples. visible light wave-band absorption because of the presence of rGO. The band gap of $\mathrm{g}-\mathrm{C}_{3} \mathrm{~N}_{4}$ and $\mathrm{g}-\mathrm{C}_{3} \mathrm{~N}_{4} / \mathrm{rGO}$ samples were estimated with the Kubelka-Munk function, which decreased from 2.70 to $2.42 \mathrm{eV}$, as the designed GO content increased from $0 \%$ to $5 \%$. The high light harvesting efficiency of the g- $\mathrm{C}_{3} \mathrm{~N}_{4} / \mathrm{rGO}$ hybrid results from rGO possessing a strong absorption in the visible light region and the $\pi-\pi$ stacking by the assembly of $\mathrm{g}-\mathrm{C}_{3} \mathrm{~N}_{4}$ and $\mathrm{rGO}$.

The specific surface area of the samples was measured by the $\mathrm{N}_{2}$ adsorption-desorption analysis (Fig. 7) and calculated using the Brunauer-Emmett-Teller (BET) model. The specific surface area of bulk g- $\mathrm{C}_{3} \mathrm{~N}_{4}$ was $6.6 \mathrm{~m}^{2} / \mathrm{g}$, and increased from 7.2 to $14.7 \mathrm{~m}^{2} / \mathrm{g}$ for the $\mathrm{g}-\mathrm{C}_{3} \mathrm{~N}_{4} / \mathrm{rGO}$ samples as the designed GO content increased from $0.5 \%$ to $5 \%$. The higher specific surface area of the g- $\mathrm{C}_{3} \mathrm{~N}_{4} / \mathrm{rGO}$ sample indicates more adsorption sites for reactants, which is beneficial for the photocatalytic reaction.

Fig. 8 shows Mott-Schottky (MS) plots, $1 / \mathrm{C}^{2}$ versus potential, for the $\mathrm{g}-\mathrm{C}_{3} \mathrm{~N}_{4}$ and $\mathrm{g}-\mathrm{C}_{3} \mathrm{~N}_{4} / \mathrm{rGO}-1$. The intersection point of the potential and linear potential curves provides a flat band potential, which, in this case, is approximately -1.12 and $-0.85 \mathrm{~V}$ versus SCE for $\mathrm{g}-\mathrm{C}_{3} \mathrm{~N}_{4}$ and $\mathrm{g}-\mathrm{C}_{3} \mathrm{~N}_{4} / \mathrm{rGO}-1$, respectively. g- $\mathrm{C}_{3} \mathrm{~N}_{4} / \mathrm{rGO}-1$ exhibits a positive shift of the flat-band potential

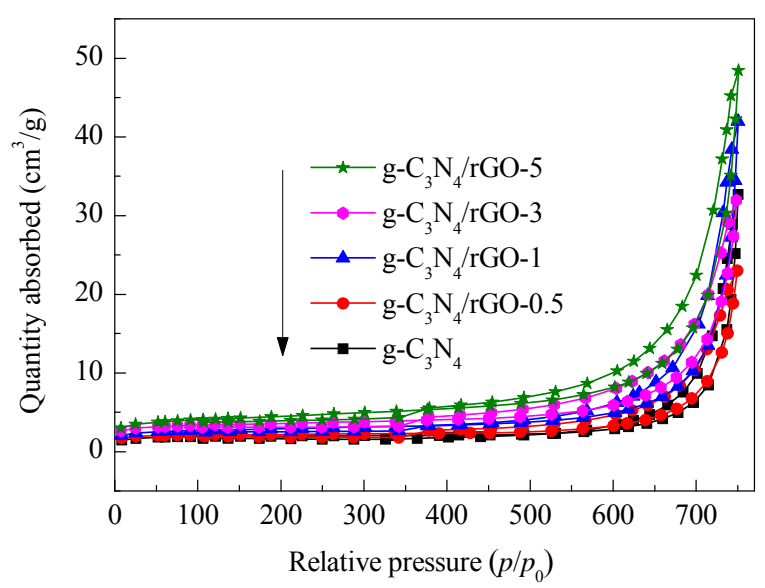

Fig. 7. $\mathrm{N}_{2}$ adsorption-desorption isotherms of g- $\mathrm{C}_{3} \mathrm{~N}_{4}$ and $g-\mathrm{C}_{3} \mathrm{~N}_{4} / \mathrm{rGO}$ samples.

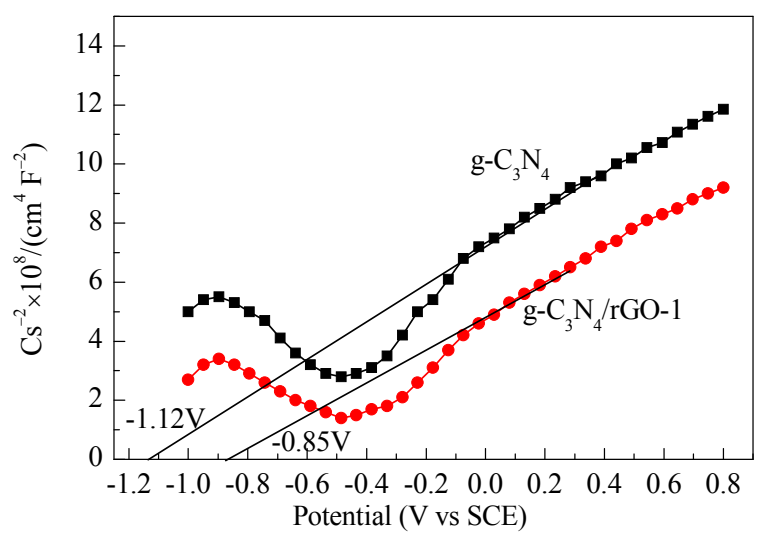

Fig. 8. Mott-Schottky (MS) plots of the different catalyst film electrodes. The MS plots were obtained at a frequency of $1 \mathrm{kHz}$ in an aqueous solution of $\mathrm{Na}_{2} \mathrm{SO}_{4}(0.1 \mathrm{~mol} / \mathrm{L})$. 
when compared with g- $\mathrm{C}_{3} \mathrm{~N}_{4}$. According to the value of the band gap (Fig. 6), the estimated positions of the valence band maximum (VBM) are 1.58 and $1.74 \mathrm{~V}$ versus SCE for $\mathrm{g}-\mathrm{C}_{3} \mathrm{~N}_{4}$ and g- $\mathrm{C}_{3} \mathrm{~N}_{4} / \mathrm{rGO}-1$, respectively. The VBM of g- $\mathrm{C}_{3} \mathrm{~N}_{4} / \mathrm{rGO}-1$ is $0.16 \mathrm{~V}$ lower than that of $\mathrm{g}-\mathrm{C}_{3} \mathrm{~N}_{4}$. The lowering of the VBM theoretically indicates that $\mathrm{g}-\mathrm{C}_{3} \mathrm{~N}_{4} / \mathrm{rGO}-1$ has a stronger oxidation ability. In addition, it is noteworthy that the slope of the linear region for the $\mathrm{g}-\mathrm{C}_{3} \mathrm{~N}_{4} / \mathrm{rGO}-1$ electrode is lower in value, which suggests a higher donor density. This has been proved by the fact that the photocurrent of the $\mathrm{g}-\mathrm{C}_{3} \mathrm{~N}_{4} / \mathrm{rGO}-1$ sample is higher than that of the $\mathrm{g}-\mathrm{C}_{3} \mathrm{~N}_{4}$ sample. Therefore, the higher separation efficiency of electron-hole pairs and the stronger oxidation ability are of key importance for the enhanced photocatalytic activity.

\subsection{Photocatalytic activity and photocurrent response}

The photocatalytic activities of the as-prepared samples were evaluated from the degradation of 2,4-DCP and RhB solutions under visible light irradiation $(\lambda>420 \mathrm{~nm})$, as shown in Fig. 8(a) and (b). In the control experiment, no degradation of RhB or 2,4-DCP was observed in the absence of photocatalyst. Fig. 9 shows that all the $\mathrm{g}-\mathrm{C}_{3} \mathrm{~N}_{4} / \mathrm{rGO}$ composites exhibited a higher visible light photocatalytic activity than pure $\mathrm{g}-\mathrm{C}_{3} \mathrm{~N}_{4}$, suggesting that the introduction of rGO can improve the photo-oxidation ability of $\mathrm{g}-\mathrm{C}_{3} \mathrm{~N}_{4}$. The photocatalytic activities of the g- $\mathrm{C}_{3} \mathrm{~N}_{4} / \mathrm{rGO}$ composites increased gradually with the increase of rGO content and reached the optimum activity when the content of rGO was $1.0 \%$. The photocatalytic activity of g- $\mathrm{C}_{3} \mathrm{~N}_{4} / \mathrm{rGO}-1$ was 1.49 times higher than pure g- $\mathrm{C}_{3} \mathrm{~N}_{4}$ for 2,4-DCP degradation, and for $\mathrm{RhB}$, the photocatalytic actvity increased by a factor of 1.52 . When the rGO content increased to than $1.0 \%$, a further increased to $3.0 \%$ or $5.0 \%$, it caused a rapid decrease in the photocatalytic activity. This decrease can be attributed to the increase in the opacity and light scattering, leading to a decrease in the amount of irradiation passing through the reaction suspension solution.

Fig. 10 shows the transient photocurrent density responses of bulk g- $\mathrm{C}_{3} \mathrm{~N}_{4}$ and g- $\mathrm{C}_{3} \mathrm{~N}_{4} / \mathrm{rGO}-1$ electrodes with light on/off cycles under visible light irradiation $(\lambda>420 \mathrm{~nm})$. The recombination efficiency of the photogenerated charge carriers is directly correlated with the transient photocurrent responses

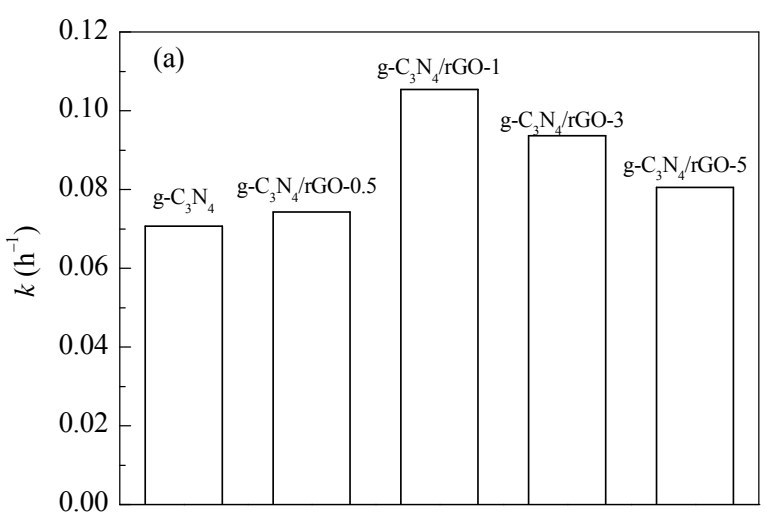

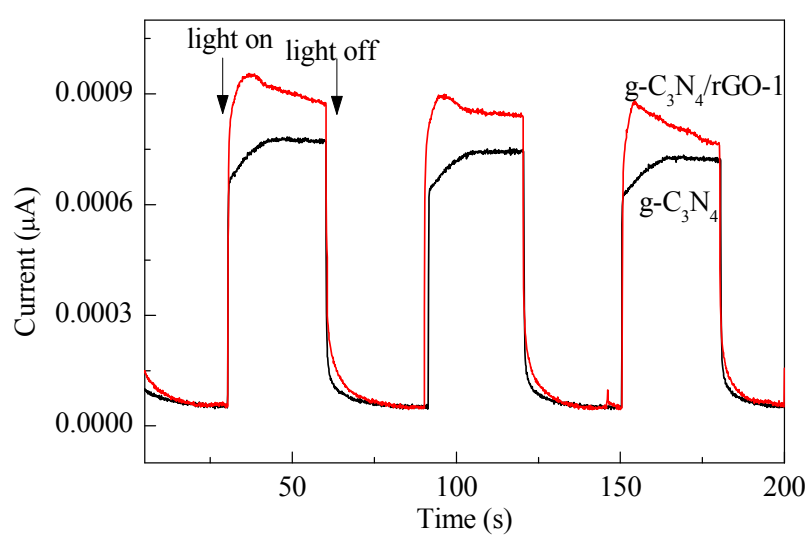

Fig. 10. The transient photocurrent density responses of pure g- $\mathrm{C}_{3} \mathrm{~N}_{4}$ and $\mathrm{g}-\mathrm{C}_{3} \mathrm{~N}_{4} / \mathrm{rGO}-1$ sample electrodes with light on/off cycles under visible light irradiation $(\lambda>420 \mathrm{~nm})$.

of the photocatalyst [43-46]. Compared with pure $\mathrm{g}-\mathrm{C}_{3} \mathrm{~N}_{4}$, it is clear that the photocurrent over $\mathrm{g}-\mathrm{C}_{3} \mathrm{~N}_{4} / \mathrm{rGO}-1$ was greatly improved. The enhanced photocurrent over the $\mathrm{g}-\mathrm{C}_{3} \mathrm{~N}_{4} / \mathrm{rGO}-1$ sample suggests a higher separation efficiency of the photogenerated electron-hole pairs and longer lifetime of the photogenerated charge carriers than that of pure $\mathrm{g}-\mathrm{C}_{3} \mathrm{~N}_{4}$, which can help to enhance the photocatalytic activity.

\subsection{Proposed mechanism for photocatalytic activity enhancement}

The PL technique is often used to study the recombination of electrons and holes in the process of photocatalytic reaction in semiconductors [47]. The photoluminescence spectra of pure g- $\mathrm{C}_{3} \mathrm{~N}_{4}, \mathrm{~g}-\mathrm{C}_{3} \mathrm{~N}_{4} / \mathrm{rGO}-0.5$, g- $\mathrm{C}_{3} \mathrm{~N}_{4} / \mathrm{rGO}-1, \mathrm{~g}-\mathrm{C}_{3} \mathrm{~N}_{4} / \mathrm{rGO}-3$ and g- $\mathrm{C}_{3} \mathrm{~N}_{4} / \mathrm{rGO}-5$ photocatalysts are shown in Fig. 10. Pure g- $\mathrm{C}_{3} \mathrm{~N}_{4}$ showed a strong peak in the PL spectrum, while with the introduction of $\mathrm{rGO}$, the composites exhibited a lower peak than pure g- $\mathrm{C}_{3} \mathrm{~N}_{4}$. The g- $\mathrm{C}_{3} \mathrm{~N}_{4} / \mathrm{rGO}-1$ sample showed the lowest peak, which means it had the highest electronic transmission efficiency, and the electron-hole recombination was effectively suppressed. Hence, we can conclude that rGO successfully hybridizes with $\mathrm{g}-\mathrm{C}_{3} \mathrm{~N}_{4}$ and the higher separation efficiency of the photogenerated charges is the direct reason for the enhanced photocatalytic activities of the $\mathrm{g}-\mathrm{C}_{3} \mathrm{~N}_{4}$ and $\mathrm{rGO}$ composites.

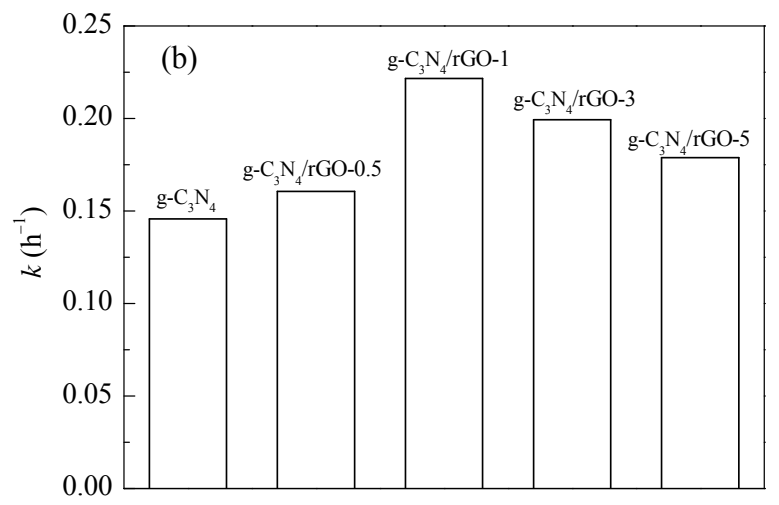

Fig. 9. Photodegradation of 2,4-DCP (a) and RhB (b) using different catalysts under visible light irradiation. 


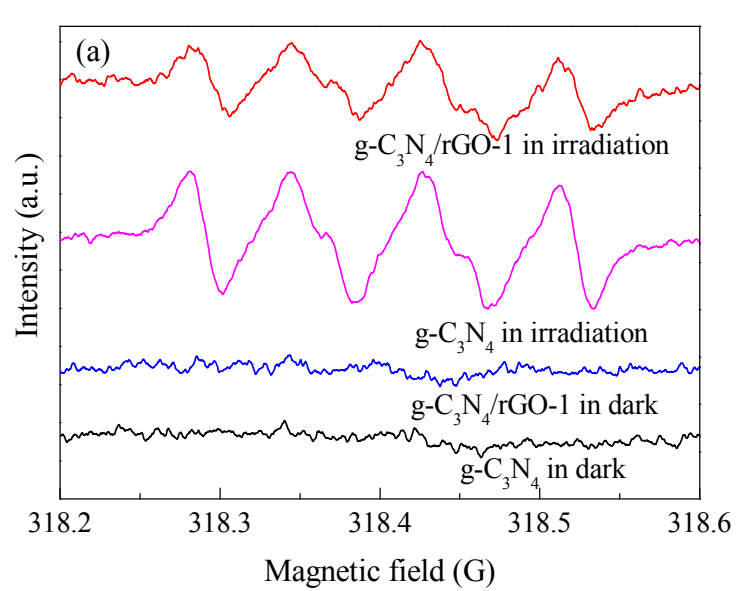

Fig. 11. ESR spectra of radical adducts trapped by DMPO. (a) DMPO DMPO- $\cdot \mathrm{OH}$ radical species detected for the samples dispersed in water.

As is known, all the reactive oxygen species (ROS), such as superoxide radicals $\left(\mathrm{O}_{2}{ }^{-}\right)$and hydroxyl radicals $(\bullet \mathrm{OH})$, are mainly involved in the photocatalytic degradation of dyes in water [48]. To probe the nature of the ROS generated over g- $\mathrm{C}_{3} \mathrm{~N}_{4}$ and the $\mathrm{g}-\mathrm{C}_{3} \mathrm{~N}_{4} / \mathrm{rGO}-1$ composite during visible light irradiation, the ESR spectra of DMPO-trapped $\bullet \mathrm{OH}$ in an aqueous medium and DMPO-trapped $\mathrm{O}_{2}{ }^{--}$in a methanol medium were investigated. As shown in Fig. 11, in a dark environment, neither g- $\mathrm{C}_{3} \mathrm{~N}_{4}$ nor g- $\mathrm{C}_{3} \mathrm{~N}_{4} / \mathrm{rGO}-1$ shows a signal. Under irradiation with visible light, $\mathrm{g}-\mathrm{C}_{3} \mathrm{~N}_{4}$ shows a stronger response signal of $\mathrm{O}_{2} \cdot$ - (Fig. 12(a)) than g- $\mathrm{C}_{3} \mathrm{~N}_{4} / \mathrm{rGO}-1$, while the signal of $\bullet \mathrm{OH}$ for $g-\mathrm{C}_{3} \mathrm{~N}_{4} / \mathrm{rGO}-1$ (Fig. 12(b)) is stronger than that of $\mathrm{g}-\mathrm{C}_{3} \mathrm{~N}_{4}$. This fact is directly related to the change of the band gap structure of $\mathrm{g}-\mathrm{C}_{3} \mathrm{~N}_{4}$. The g- $\mathrm{C}_{3} \mathrm{~N}_{4} / \mathrm{rGO}$ has a more positive VB position compared with the bulk g- $\mathrm{C}_{3} \mathrm{~N}_{4}$, suggesting that the holes on the VB of g- $\mathrm{C}_{3} \mathrm{~N}_{4} / \mathrm{rGO}$ might possess a stronger oxidation ability to react with $\mathrm{H}_{2} \mathrm{O}$ to produce more $\bullet \mathrm{OH}$. The $\mathrm{VB}$ of $\mathrm{g}-\mathrm{C}_{3} \mathrm{~N}_{4}$ is not sufficiently positive to oxidize water and generate $\bullet \mathrm{OH}$, but an obvious $\bullet \mathrm{OH}$ signal can be observed, which is generated by $\mathrm{O}_{2} \bullet$.

Based on the above results, a mechanism for the separation and transportation of electron-hole pairs at the interface of g- $\mathrm{C}_{3} \mathrm{~N}_{4} / \mathrm{rGO}$ photocatalysts is proposed in Scheme 1 . Under visible light irradiation, electrons $\left(\mathrm{e}^{-}\right)$are excited from the VB populated by $\mathrm{N} 2 p$ orbitals to the CB formed by $\mathrm{C} 2 p$ orbitals of

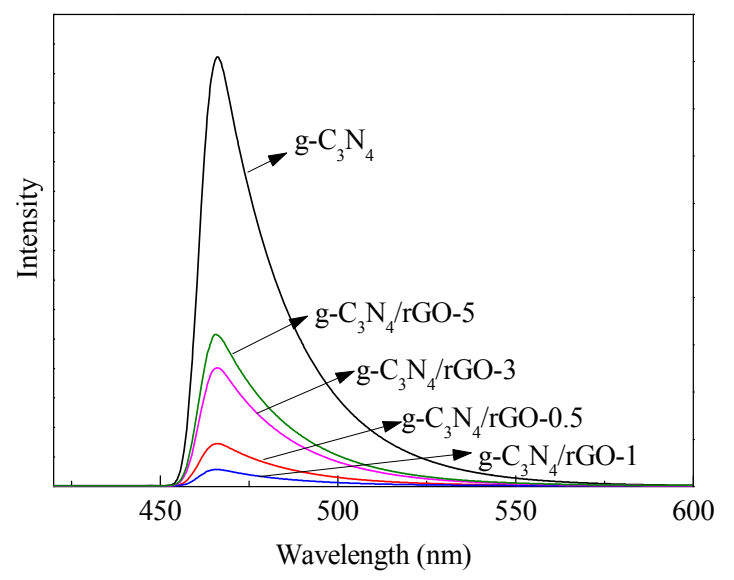

Fig. 12. PL spectra of pure g- $\mathrm{C}_{3} \mathrm{~N}_{4}$ and the g- $\mathrm{C}_{3} \mathrm{~N}_{4} / \mathrm{rGO}$ photocatalysts.

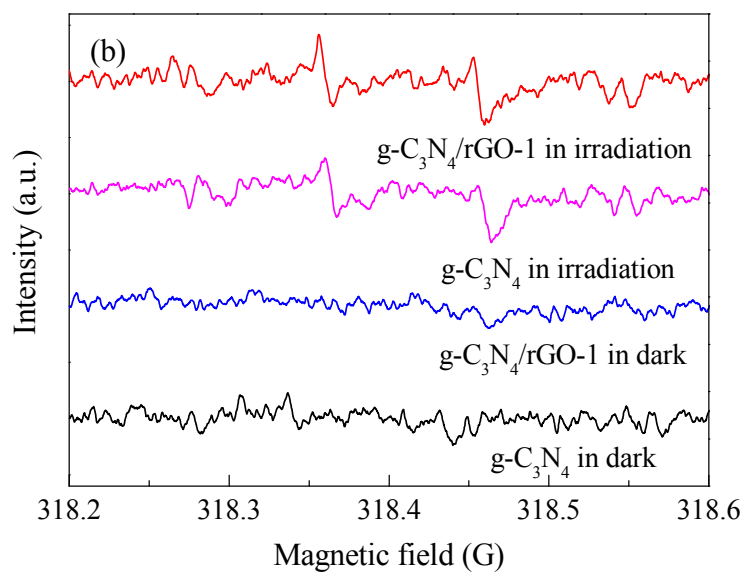

g- $\mathrm{C}_{3} \mathrm{~N}_{4}$, creating holes $\left(\mathrm{h}^{+}\right)$in the VB. Usually, these charge carriers can quickly recombine and only a small number of electrons can participate in the photocatalytic reaction. However, when $\mathrm{rGO}$ was hybridized on the surface of $\mathrm{g}-\mathrm{C}_{3} \mathrm{~N}_{4}$ and formed a conjugated structure, these photogenerated electrons on the $\mathrm{CB}$ of $\mathrm{g}-\mathrm{C}_{3} \mathrm{~N}_{4}$ tend to transfer to rGO owing to its excellent electronic conductivity, leading to hole-electron separation. The transferred electrons will accumulate on the surface of rGO and presumably as interface bound exciton pairs to capture the adsorbed $\mathrm{O}_{2}$ on $\mathrm{g}-\mathrm{C}_{3} \mathrm{~N}_{4}$ surface to form superoxide radical $\left(\mathrm{O}_{2}{ }^{-}\right)$, and then participate in photocatalytic oxidation reaction. Meanwhile, on the VB of $g-\mathrm{C}_{3} \mathrm{~N}_{4}$, the high separation efficiency of photoinduced electron-hole pairs could result in the increase of the number of holes, which could directly improve the photocatalytic activity. Furthermore, the introduction of rGO could lower the VB position of $\mathrm{g}_{-} \mathrm{C}_{3} \mathrm{~N}_{4}$ and improve the photo-oxidation ability in the degradation of organic pollutants.

\section{Conclusions}

A simple one-pot method is used to prepare a g- $\mathrm{C}_{3} \mathrm{~N}_{4} / \mathrm{rGO}$ nanohybrid photocatalyst. rGO can easily hybridize with $\mathrm{g}-\mathrm{C}_{3} \mathrm{~N}_{4}$

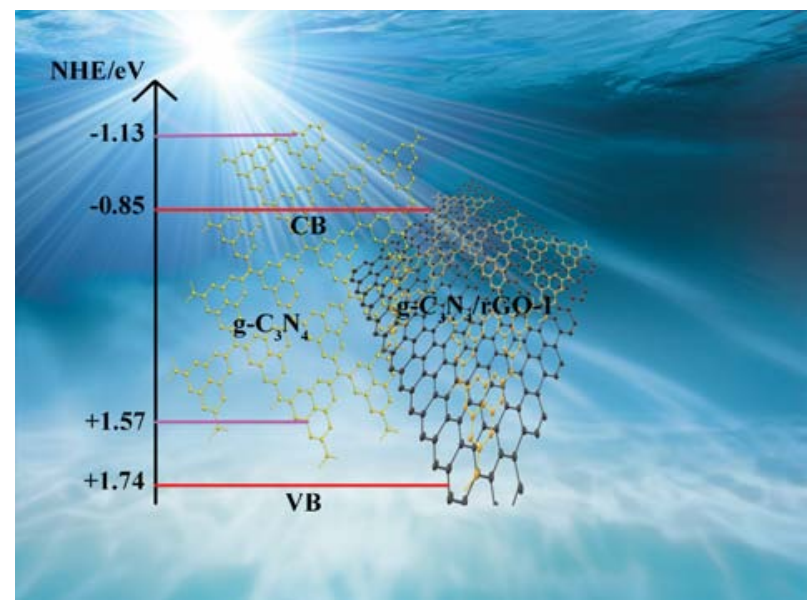

Scheme 1. Schematic drawing illustrating the mechanism of charge separation and the photocatalytic process over g- $\mathrm{C}_{3} \mathrm{~N}_{4}$ and $g-\mathrm{C}_{3} \mathrm{~N}_{4} / \mathrm{rGO}$ photocatalysts under visible light irradiation. 
through strong $\pi-\pi$ stacking interactions. The introduction of rGO can not only improve the electron transfer, but also lowers the VB location of $\mathrm{g}-\mathrm{C}_{3} \mathrm{~N}_{4}$, resulting in the enhancement of the photo-oxidation ability. The g- $\mathrm{C}_{3} \mathrm{~N}_{4} / \mathrm{rGO}$ composites exhibit a higher photocatalytic activity than pure g- $\mathrm{C}_{3} \mathrm{~N}_{4}$ for 2,4 -DCP and $\mathrm{RhB}$ degradation under visible light irradiation. When the weight ratio of $\mathrm{rGO}$ in the $\mathrm{g}-\mathrm{C}_{3} \mathrm{~N}_{4} / \mathrm{rGO}$ composites is $1 \%$, the maximum photocatalytic activity is achieved.

\section{Acknowledgement}

This work was supported by the National Natural Science Foundation of China (21577132), the Fundamental Research Funds for the Central Universities (2652015225), National High Technology Research and Development Program of China (2012AA062701), Students Innovation and Entrepreneurship Training Program 2015 of China University of Geosciences (201511415069).

\section{References}

[1] A. Fujishima, K. Honda, Nature, 1972, 238, 37-38.

[2] J. G. Yu, G. P. Dai, Q. J. Xiang, M. Jaroniec, J. Mater. Chem., 2011, 21, 1049-1057.

[3] A. L. Linsebigler, G. Q. Lu, J. T. Yates, Chem. Rev., 1995, 95, 735-758.

[4] A. Wold, Chem. Mater., 1993, 5, 280-283.

[5] D. M. Chen, H. L. Zhu, X. Wang, Appl. Surf. Sci., 2014, 319, 158-166.

[6] H. N. Kim, T. W. Kim, I. Y. Kim, S. J. Hwang, Adv. Funct. Mater., 2011, 21, 3111-3118.

[7] V. B. R. Boppana, R. F. Lobo, J. Catal., 2011, 281, 156-168.

[8] Q. Li, B. D. Guo, J. G. Yu, J. R. Ran, B. H. Zhang, H. J. Yan, J. R. Gong, J. Am. Chem. Soc., 2011, 133, 10878-10884.

[9] Y. J. Cui, Chin. J. Catal., 2015, 36, 372-379.

[10] Y. Zhang, D. A. J. M. Ligthart, P. Liu, L. Gao, T. M. W. G. M. Verhoeven, E. J. M. Hensen, Chin. J. Catal., 2014, 35, 1944-1954.

[11] K. Maeda, M. Higashi, B. Siritanaratkul, R. Abe, K. Domen, J. Am. Chem. Soc., 2011, 133, 12334-12337.
[12] L. W. Zhang, T. G. Xu, X. Zhao, Y. F. Zhu, Appl. Catal. B., 2010, 98, 138-146.

[13] Q. Li, X. Zhao, J. Yang, C. J. Jia, Z. Jin, W. L. Fan, Nanoscale, 2015, 7, 18971-18983

[14] R. A. He, S. W. Cao, P. Zhou, J. G. Yu, Chin. J. Catal., 2014, 35, 989-1007.

[15] J. Q. Wen, X. Li, W. Liu, Y. P. Fang, J. Xie, Y. H. Xu, Chin. J. Catal., 2015, 36, 2049-2070.

[16] Y. Ohko, I. Ando, C. Niwa, T. Tatsuma, T. Yamamura, T. Nakashima, Y. Kubota, A. Fujishima, Environ. Sci. Technol., 2001, 35, 2365-2368.

[17] K. Ding, D. Wang, P. Yang, X. Cheng, Mater. Res. Bull., 2016, 74, 311-318.

[18] M. A. Behnajady, N. Modirshahla, R. Hamzavi, J. Hazard. Mater., 2006, 133, 226-232.

[19] C. G. Tian, Q. Zhang, A. P. Wu, M. J. Jiang, Z. L. Liang, B. J. Jiang, H. G. Fu, Chem. Commun., 2012, 48, 2858-2860.

[20] S. X. Liu, Z. P. Qu, X. W. Han, C. L. Sun, X. H. Bao, Chin. J. Catal., 2004, 25, 133-137.

[21] J. Xu, Y. J. Wang, Y. F. Zhu, Langmuir, 2013, 29, 10566-10572.

[22] X. C. Wang, X. F. Chen, A. Thomas, X. Z. Fu, M. Antonietti, Adv. Mater., 2009, 21, 1609-1612.

[23] G. Liu, P. Niu, C. H. Sun, S. C. Smith, Z. G. Chen, G. Q. Lu, H. M. Cheng, J. Am. Chem. Soc., 2010, 132, 11642-11648.

[24] X. H. Li, J. S. Chen, X. C. Wang, J. H. Sun, M. Antonietti, J. Am. Chem. Soc., 2011, 133, 8074-8077.

[25] B. Zhang, T. H. Cui, Appl. Phys. Lett., 2011, 98, 231113/1-231113/3.

[26] B. R. Singh, M. Shoeb, W. Khan, A. H. Naqvi, J. Alloy Compd., 2015, 651, 598-607.

[27] J. L. Li, X. J. Liu, X. Hou, W. Qin, Z. Sun, L. K. Pan, J. Colloid Interface Sci., 2015, 458, 235-240.

[28] H. Gu, T. S. Zhou, G. Y. Shi, Talanta, 2015, 132, 871-876.

[29] Q. J. Xiang, J. G. Yu, M. Jaroniec, J. Phys. Chem. C, 2011, 115, 7355-7363.

[30] A. K. Geim, K. S. Novoselov, Nat. Mater., 2007, 6, 183-191.

[31] X. C. Wang, K. Maeda, A. Thomas, K. Takanabe, G. Xin, J. M. Carlsson, K. Domen, M. Antonietti, Nat. Mater., 2009, 8, 76-80.

[32] W. S. Hummers Jr., R. E. Offeman, J. Am. Chem. Soc., 1958, 80, 1339-1339.

\section{Graphical Abstract}

Chin. J. Catal., 2017, 38: 278-286 doi: 10.1016/S1872-2067(16)62561-5

\section{Enhanced photochemical oxidation ability of carbon nitride by} $\pi-\pi$ stacking interactions with graphene

Qiang Hao, Simeng Hao, Xiuxiu Niu, Xun Li, Daimei Chen*, Hao Ding* China University of Geosciences

rGO can easily hybridized with g- $\mathrm{C}_{3} \mathrm{~N}_{4}$ through $\pi-\pi$ stacking interactions, as a result, the VB became more positive and the photooxidation ability was enhanced.

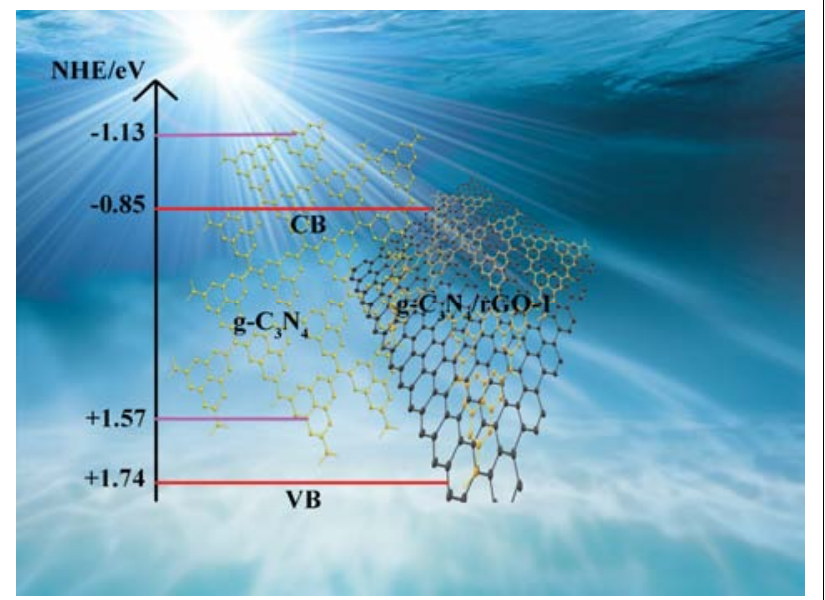


[33] F. Dong, Y. J. Sun, L. W. Wu, M. Fu, Z. B. Wu, Catal. Sci. Technol., 2012, 2, 1332-1335.

[34] J. Gao, Y. Zhou, Z. S. Li, S. C. Yan, N. Y. Wang, Z. G. Zou, Nanoscale, 2012, 4, 3687-3692.

[35] Y. C. Zhao, D. L. Yu, H. W. Zhou, Y. J. Tian, O. Yanagisawa, J. Mater. Sci., 2005, 40, 2645-2647.

[36] X. F. Li, J. Zhang, L. H. Shen, Y. M. Ma, W. W. Lei, Q. L. Cui, G. T. Zou, Appl. Phys. A, 2009, 94, 387-392.

[37] L. Liu, D. Ma, H. Zheng, X. J. Li, M. J. Cheng, X. H. Bao, Microporous Mesoporous Mater., 2008, 110, 216-222.

[38] L. Liu, H. J. Liu, Y. P. Zhao, Y. Q. Wang, Y. Q. Duan, G. D. Gao, M. Ge, W. Chen, Environ. Sci. Technol., 2008, 42, 2342-2348.

[39] Y. B. Li, H. M. Zhang, P. R. Liu, D. Wang, Y. Li, H. J. Zhao, Small, 2013, 9, 3336-3344.
[40] H. F. Yang, F. H. Li, C. S. Shan, D. X. Han, Q. X. Zhang, L. Niu, A. Ivaska, J. Mater. Chem., 2009, 19, 4632-4638.

[41] Y. Sun, T. Xiong, Z. Ni, J. Liu, F. Dong, W. Zhang and W. K. Ho, Appl. Surf. Sci., 2015, 358, 356-362.

[42] H. Liu, S. A. Cheng, M. Wu, H. J. Wu, J. Q. Zhang, W. Z. Li, C. N. Cao, J. Phys. Chem. A, 2000, 104, 7016-7020.

[43] W. H. Leng, Z. Zhang, J. Q. Zhang, C. N. Cao, J. Phys. Chem. B, 2005, 109, 15008-15023.

[44] H. Park, W. Choi, J. Phys. Chem. B, 2003, 107, 3885-3890.

[45] Y. S. Xu, W. D. Zhang, ChemCatChem, 2013, 5, 2343-2351.

[46] T. Hirakawa, Y. Nosaka, Langmuir, 2002, 18, 3247-3254.

[47] M. R. Hoffmann, S. T. Martin, W. Y. Choi, D. W. Bahnemann, Chem. Rev., 1995, 95, 69-96.

\section{通过 $\mathrm{rGO}$ 与 $\mathrm{g}-\mathrm{C}_{3} \mathrm{~N}_{4}$ 的 $\pi-\pi$ 堆积作用提高氮化碳光化学氧化能力}

郝 强, 郝思濛, 牛秀秀, 李 巽, 陈代梅, 丁 浩 ${ }^{*}$ 中国地质大学(北京), 材料科学与工程学院, 北京 100083

摘要: 石墨相氮化碳 $\left(\mathrm{g}-\mathrm{C}_{3} \mathrm{~N}_{4}\right)$ 具有较高的催化活性、良好的生物相容性、廉价易得、低毒性等特点, 因而受到了广泛的关 注. $\mathrm{g}-\mathrm{C}_{3} \mathrm{~N}_{4}$ 的禁带宽度为 $2.7 \mathrm{eV}$, 可被可见光激发, 相对于二氧化钛和氧化锌, 它对可见光具有更高的太阳光利用率. 尽管 理论上 $\mathrm{g}-\mathrm{C}_{3} \mathrm{~N}_{4}$ 是类似于石墨烯结构的二维材料, 但通常情况下 $\mathrm{g}-\mathrm{C}_{3} \mathrm{~N}_{4}$ 却是层层堆积起来的三维体相结构. 从而导致了其比 表面积降低, 催化反应过程中与反应物接触面积小. 同时又使光照下生成的载流子不能迅速传递到材料表面参与反应, 大 大降低了 $\mathrm{g}-\mathrm{C}_{3} \mathrm{~N}_{4}$ 光生载流子的分离和传递效率. 另外, 作为一种可见光催化剂, $\mathrm{g}-\mathrm{C}_{3} \mathrm{~N}_{4}$ 的禁带宽度比一般的无机半导体光 催化剂窄, 仅能够吸收部分可见光. 本文利用原位㶲烧法制备了 $\mathrm{g}-\mathrm{C}_{3} \mathrm{~N}_{4} / \mathrm{rGO}$ 复合光催化剂, 以罗丹明 $\mathrm{B}$ 和 $2,4-$ 二氯酚为目标 探针分子, 考察了其可见光催化活性. 这对于设计开发其他具有共轭大 $\pi$ 键的光催化体系, 具有一定的借鉴意义.

$X$ 射线衍射 (XRD), 傅里叶变换红外光谱(FTIR), X射线光电子能谱(XPS)和激光共聚焦拉曼光谱(Raman)结果表明, 氧 化石墨烯成功地被还原为石墨烯, 并成功地引入到了 $\mathrm{g}-\mathrm{C}_{3} \mathrm{~N}_{4}$ 中去. 在三聚氨胺聚合的过程中, 石墨烯被夹杂在氮化碳的片 层中间, 有利于形成 $\pi-\pi$ 共轭作用.

复合光催化剂 $\mathrm{C}_{3} \mathrm{~N}_{4} / \mathrm{rGO}$ 的带边发生明显的红移, 在可见光区域内的吸收强度也有所增加, 因而有利于其可见光催化活 性的提高. 通过外推法算得 $\mathrm{g}-\mathrm{C}_{3} \mathrm{~N}_{4}$ 和 $\mathrm{C}_{3} \mathrm{~N}_{4} / \mathrm{rGO}-1$ 复合光催化剂的带隙宽度分别为 2.70 和 $2.42 \mathrm{eV}$. 为了更好地考察复合光催 化剂 $\mathrm{C}_{3} \mathrm{~N}_{4} / \mathrm{rGO}$ 的能带结构的变化, 通过光电化学的手段对其进行进一步的研究. 莫特-肖特基结果表明该半导体是 $\mathrm{n}$ 型. 计 算得出 $\mathrm{g}-\mathrm{C}_{3} \mathrm{~N}_{4}$ 和 $\mathrm{C}_{3} \mathrm{~N}_{4} / \mathrm{rGO}$ 复合光催化剂的平带电势分别为 -1.12 和 $-0.85 \mathrm{~V}$ 对甘录标准电极, $\mathrm{C}_{3} \mathrm{~N}_{4} / \mathrm{rGO}$ 复合光催化剂的平带 电位发生明显的正移. 由此分别确定 $\mathrm{g}-\mathrm{C}_{3} \mathrm{~N}_{4}$ 和 $\mathrm{C}_{3} \mathrm{~N}_{4} / \mathrm{rGO}$ 复合光催化剂的价带底则位于 1.58 和 $1.74 \mathrm{~V}$ 对甘录标准电极. 相比 $\mathrm{g}-\mathrm{C}_{3} \mathrm{~N}_{4}, \mathrm{~g}-\mathrm{C}_{3} \mathrm{~N}_{4} / \mathrm{rGO}$ 复合光催化剂的价带位置的降低意味着其具有更强光氧化的能力, 且比表面积的增大也有利于光催化 反应. 结果发现, 石墨烯与 $\mathrm{g}-\mathrm{C}_{3} \mathrm{~N}_{4}$ 的比例为 $1 \%$ 时, 复合样品的光催化性能最佳, 对罗丹明 $\mathrm{B}$ 和 $2,4-$ 二氯酚的降解性能均有提 高.

关键词: 石墨相氮化碳; 还原氧化石墨烯; $\pi-\pi$ 堆积; 光催化; 相互作用

收稿日期: 2016-08-20. 接受日期: 2016-09-26. 出版日期: 2017-02-05.

*通讯联系人. 电话: 15801558907; 传真: (010)82322974; 电子信箱: chendaimei@cugb.edu.cn

\#通讯联系人. 电子信箱: dinghao@cug.edu.cn

基金来源：国家自然科学基金(21577132); 国家高技术研究发展计划(863计划, 2012AA062701); 中央高校基本科研业务费 (2652015225); 2015中国地质大学(北京)大学生创新创业训练计划(201511415069)

本文的英文电子版由Elsevier出版社在ScienceDirect上出版(http://www.sciencedirect.com/science/journal/18722067). 